\title{
The Relationship Between Tourism Destination Image, Perceived Value and Post-visiting Behavioral Intention of Chinese Tourist to Thailand
}

\author{
Bing Zhang ${ }^{1}$, \& Eksiri Niyomsilp ${ }^{2}$ \\ ${ }^{1}$ PhD Candidate, Management, School of Management, Shinawatra University, Thailand \\ ${ }^{2}$ School of Management, Shinawatra University, Thailand \\ Correspondence: Bing Zhang, PhD Candidate, Management, School of Management, Shinawatra University, \\ Thailand.
}

Received: September 21, 2020

Accepted: October 19, 2020

Online Published: October 23, 2020

doi:10.5539/ibr.v13n11p96

URL: https://doi.org/10.5539/ibr.v13n11p96

\begin{abstract}
The aim of this research was to study the relationship between tourism destination image, perceived value and post-visiting behavioral intention of Chinese tourist to Thailand. The methodology of this study is quantitative research in which questionnaire is the major tool in collected the primary data for analysis. The total sample of 400 Chinese tourists to Thailand was obtained for the analysis. The results of this study indicated that there is a significant positive impact of destination image on post-visiting behavioral intention; There is a significant impact of perceived value on post-visiting behavioral intention; There is a significant impact of destination image on perceived value; Perceived value plays a partial mediating role in the influence of tourist destination image on tourists' post-visiting behavioral intention. In order to enhance the competitiveness of tourism destinations, the study results suggest that organizations and marketers relevant to tourism industry in Thailand should improve the image of tourism destination and enhance the perceived value of tourists.
\end{abstract}

Keywords: tourism destination image, post-visiting behavioral intention, perceived value

\section{Introduction}

Since entering the 21st century, the market competition among tourist destinations has become more fierce. In order to maintain market competitiveness, tourist destinations face the dual pressure of developing new markets and maintaining existing markets. Because the tourist destination is relatively familiar with the existing market and can carry out marketing activities to the target market at its own preference, it will save marketing costs to maintain the existing market rather than to open up a new one. In addition, revisiting tourists not only stay in the tourist destination longer than the first-time tourists, but also do free publicity for the tourist destination in the form of word-of-mouth publicity. Therefore, attracting tourists to visit again is of great significance to the survival and development of tourist destinations.

\section{Research Questions}

According to the research statement of the problems explained above, this research make an effort to answer the following four questions:

1. What's impact of tourism destination image on perceived value

2. What's impact of perceived value on post-visiting behavioral intention?

3. What's impact of tourism destination image on post-visiting behavioral intention.

4. How does perceived value affect the relationship between destination image and post-visiting behavioral intention?

\section{Research Objectives}

1.To identify study the impact of tourism destination image on perceived value.

2.To study the impact of perceived value on post-visiting behavioral intention.

3.To examine the impact of destination image on post-visiting behavioral intention. 
4. To examine the mediating role of perceived value between

destination image and post-visiting behavioral intention.

\section{Conceptual Framework}

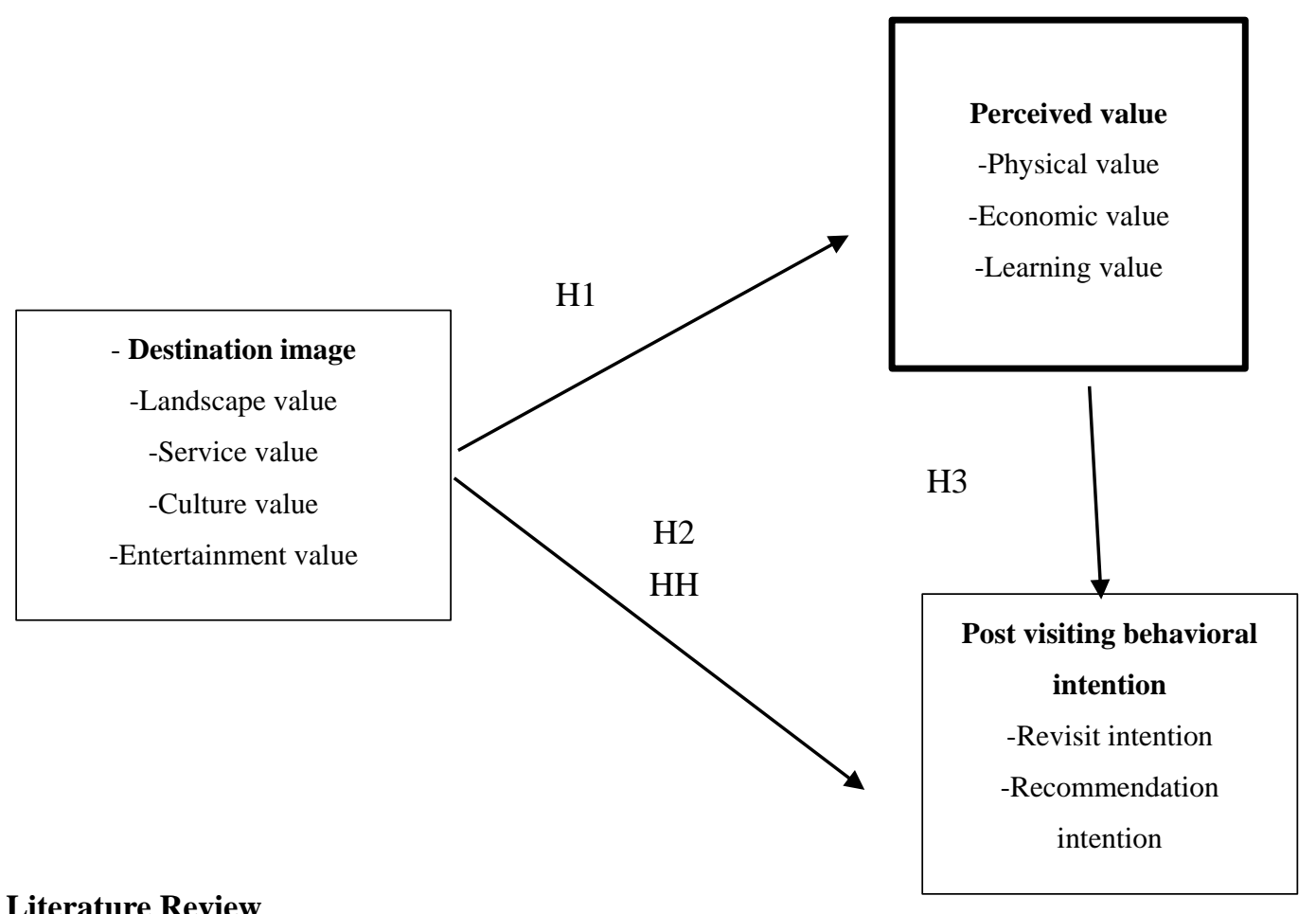

\section{Literature Review}

\subsection{Connotation of Tourism Destination Image}

Chi and Qu (2008) proposed, The psychological representation of the basic understanding, feeling and overall perception of certain destinations mastered by individuals is called destination image. Guan Xinhua et al (2015) think that the overall impression of the individual is the image of the tourist destination. Chen et al (2016) pointed out from the perspective of tourism marketing, For potential visitors, The destination image can show the advantages and disadvantages of the destination, It is an important foundation of destination marketing. Endah (2017) put forward that the image of tourist destination is the individual's own cognition of destination, can act as a driver of the decision making process. From the above review of the relevant literature. Based on the above review of its concept, This paper adopts the generally accepted definition of tourist destination image, That is, all the views, including beliefs, opinions and impressions, formed by tourists on tourist destinations.

\subsection{Tourism Destination Image Study}

Since 1970s, the study of tourism destination image has gradually become an important subject in the field of tourism destination marketing Scholars study the types of tourist destination images from various perspectives. Gunn(1988) from the perspective of tourists, Tourism destination image is divided into two categories: original image and induced image. The original image refers to the impression of the tourist before reaching the destination, This impression is mostly because of news, books, television, network and other media spread and formed; Induced image is the tourist destination through a variety of channels to introduce tourists about the advertising, publicity, promotion and so on, So that tourists can form an impression of the place. Fakeye、 Crompton(1991) according to the previous research, Tourism destination image is divided into three categories: original image, induced image and comprehensive image. Among them, Comprehensive image refers to the comprehensive information produced by tourists after visiting their destination, It also includes previous knowledge of the site. Gartner(1993) study again optimizes the type of destination image, Put forward the "three-dimensional structure ", That is, cognitive image, emotional image and moving image. This article also describes the cognitive image, He believes that the cognitive image is not only determined by the tourists' perception of the image of the place, Also determines the non-local residents of the image of the [53] perception. Cleary(1999) through research, the tourist destination image consists of cognitive image, emotional image and 
overall image, known as "new three-dimensional structures ". Son(2005) classified from subjective to objective, The image of tourist destination is divided into conceptual image and evaluation image, Among them, Conception image refers to tourists' understanding of the environment of tourist destination, Evaluation image refers to the cognitive image and emotional image of tourists. On the basis of the above four dimensions, the article further refines the image of the tourist destination emotion into six dimensions, adding the two dimensions of "disliked, liked, interesting and boring.

Bai Liming (2007), a domestic scholar, constructed a "three-dimensional measurement model of tourism destination image" from the perspective of methodology: the actual image, the launch image and the perceived image of the tourism destination image of Yangshuo in Guilin are scientifically and comprehensively measured and compared. Hu Xianyang, Bai Kai and Wang Li (2013), based on the theory of image restoration, summed up the image restoration table of tourist destination, and divided the strategy of destination image restoration into six dimensions: denial, evasion of responsibility, attack, reduction of external attack, correction action, formal greeting, recognition and apology. At present, scholars at home and abroad basically agree with the "new three-dimensional structure ", and after a more in-depth study, it also confirms that the structure is also applicable to the cultural background of China. Zhao Jingyuan, Ma Peng, Lu Zhengying (2013) divided the destination into environmental image, service facility and product image, function image; Bai Zhiping (2015) divided the destination image into scenic spot landscape natural characteristics, scenic spot reception service and management, infrastructure construction and service, cultural environment, city impression several factors; Shi can (2018) evaluated the destination image from the aspects of scenery and sanitation, scenic spot price, scenic spot service, infrastructure.

On the basis of previous studies, domestic and foreign scholars have further expounded the elements of tourism destination. Scholars at home and abroad have different views on the whole tourist destination, and the emphasis on the elements of the tourist destination image will be different. From the point of view of tourists, the experience of tourists is divided into different categories and elements. From the integrity of tourism image, let tourists give the impression of tourist destination. The following table lists scholars' research on the elements of tourist destination

\subsection{Connotation of Perceived Value}

Zeithaml (1988) through research, First put forward the concept of customer perceived value, Mainly based on the psychological perspective. He showed, In service contacts, An individual's overall assessment of goods or services. Then, Some scholars put forward different views. Woodruff (1997) in his research, Perceived value refers to the use of a product by an individual in a given situation, evaluation of the performance of the target product and the effect after use, This can facilitate or hinder the customer's own purchase intention. Morrison(1998) put forward that the perceived value of tourists is based on their own cost and income comparison, so as to psychological evaluation of the products and services provided by tourism companies. Duman and Mattila (2005) In their research, it is shown that the perceived value of tourists is the subjective result of comparing the experience of tourists in tourism with the money and time they spend. Huang Yinghua and Huang Fucai (2007) define the perceived value of tourists from the perspective of satisfying tourists' expectations. It is a comprehensive evaluation of consumption experience, preference and knowledge and their input and performance in tourism consumption. Li Wenbing and Zhang Hongmei (2010) studied the perceived value of tourists in a specific situation from the perspective of the benefits and losses experienced by tourists. It also points out that it is the overall evaluation of tourists for the various commodities and services provided to tourists by relevant personnel that meet their needs. To sum up, the perceived value of tourists used in this study is the subjective result of comparing the experience of tourists in tourism with the money and time they spend.

\subsection{Perceived Value Study}

The measurement of tourist perception value has always been a hot issue in academic circles. There are two ways to measure, One is to explore the relationship between perceived value and tourism destination image, service quality and other variables. In the literature on this category, In measuring perceived value, Most scholars adopt a holistic, non-specific approach. The foreign scholars Duman and Mattila(2005)、Chen and Tsai(2007), as well as Chen and Chen(2010) measure the perceived value by using a single dimension scale including five topics. Chinese scholars Su Lujun and Huang Fucai (2010) and Guo Anxi (2013) also used a single dimension to measure the perceived value of tourists, Includes four measurement items. Other The other is to explore the perceived value of tourists in a particular tourism situation and analyze their measurement dimensions. This type of research focuses on its multi-dimensional structure. Sanchez et al (2006) explored the perceived value of tourists to the purchase of tourism products in their article and developed a scale covering six dimensions. Ma 
Ling and Bao Jigang (2012) and Cai Weimin (2015) summed up seven dimensions of perceived value. Guo Anxi et al .2019) verify the influence mechanism of tourist perceived value dimension on revisiting intention from four dimensions of perceived value-based on the perspective of team tourists

Through the review of the relevant literature, we can see that in different situations, scholars have divided the perceived value into different dimensions. This paper mainly discusses the relationship between perceived value and other variables. Therefore, the four-dimensional scale is used to measure the perceived value of tourists.

\subsection{Connotation of Behavioral Intention}

Fishbein and Ajze(1975) studies show that behavioral intention is the willingness intensity of specific actions made by customers in the future. It has both potential real purchase actions in the future and the intention to introduce them to others for specific goals. Zeithaml et al. (1996) proposed that behavioral intention refers to people having subjective The conscious judgment of various behavioral tendencies that may occur in the future. Lee et al. (2007) and Chen and Tsai(2007) studies show that, Behavioral intention is that individuals may revisit the same destination and recommend it to others in the future. Žabkar et al .(2010) proposed, Tourist behavior intention is that tourists participate in tourism and experience tourism activities, For tourism products or services already purchased, Possible future actions, Among them, the most representative is the possible future intention of tourists and the possibility of publicity to others. Hyun et al. (2011) show that behavior intention refers to the possibility of positive evaluation, recommendation to others and possible re-occupation in the future. Li Wei (2016) believes that a series of follow-up behaviors generated by tourists under the stimulation of various elements of the consumption place are called behavioral intentions Based on the above discussion, this study adopts the existing definition, that is, the intention of tourist behavior refers to the possibility that tourists may recommend to others and re-visit themselves in the future after visiting a certain destination.

\subsection{Behavior Intention Study}

The measurement of tourist behavior intention is usually composed of multiple dimensions. Parasuraman et al. (1996) measure the customer's behavioral intention in the measurement of tourism-related research through five aspects: premium purchase intention, loyalty, internal response, behavior transformation and external response, Relevant scholars also put forward different measurement dimensions. Castro et al. (2007) summarized the future behavior intention of tourists into two indicators, They are the intention to revisit the destination and the intention to recommend the destination to others. Prayag and Ryan (2012) point out that the most commonly used variables used to capture tourist behavior intentions associated with tourist destinations include revisiting destination intentions, recommending destination intentions to others, and word of mouth dissemination. Jin et al. (2013) define behavioral intention as the possibility of revisiting the destination and the possibility of recommending the destination to relatives, friends and others in the future. Han Chunxian (2015) showed that, The measurement dimension of customer's future behavior loyalty is also applicable to the study of tourist behavior in tourism related research fields, Refers to the willingness of tourists to recommend or visit the destination again. Yang Ni et al. (2015) proposed the tourist behavior intention, With the will to recommend to others, There is also a willingness to visit again in the future. Liu Jingyan and Jing Jinjing (2015) proposed that tourist behavior intention can be measured by revisiting, sharing and recommending three indicators. Tu Hongwei et al. (2017) also used two indicators to measure tourists' behavior intention, It is also called mixed loyalty.

Through the review of relevant literature, it can be found that "recommendation" and "revisiting" are regarded as two important measurement dimensions, which have been recognized by many scholars. This paper draws lessons from many achievements and adopts "recommendation intention" and "revisiting intention" as the measurement dimension. The recommendation intention indicates the possibility that the individual introduces to the friends and relatives around him (Prayag G et al.2015). The willingness to revisit indicates the possibility of individuals returning to play in the future (Papadimitriou D et al.2015)

\section{Research Hypothesis}

\subsection{Relationship between Tourism Destination Image and Perceived Value}

The close relationship between tourist destination image and perceived value has always been the focus of scholars. Cheng and $\mathrm{Lu}$ (2013) explore the causal relationship between tourism destination image and perceived value, and the results of structural equation model show that there is a positive correlation between them. Aliman et al .(2014) investigated 482 visitors visiting lankavi in 2013 and verified the effect of three variables, namely, tourist expectation, perceived quality, and destination image, on perceived value and tourist satisfaction. regression analysis showed that destination image was positively correlated with perceived value, and 
destination image was the most important antecedent variable of tourist perceived value compared with other independent variables. Lban et al .(2015) take the festival tour as an example. The results show that the image of tourist destination affects the perceived value and further affects the intention of tourists to visit again.

\subsection{Relationship Between Perceived Value and Tourist Behavior Intention}

The perceived value of tourists will not only have an effect on the individual's decision before the trip, but also on their related behaviors after the visit (Lee et al.2007). The research shows that in-depth study of perceived value is helpful for tour operators to understand tourists' current and future behavioral intentions, and can be used as an effective predictor of tourists' behavioral intentions (Cheng et al.2013). After their investigation, Hutchinson et al. (2009) showed through data that the positive perceived value of golf tourists led to their positive behavioral intentions (such as revisiting intentions and word-of-mouth communication).Cheng and $\mathrm{Lu}$ (2013) confirmed that tourists' perceived value has a positive impact on their intention to revisit. The study of $\mathrm{Wu}$ et al. (2016) also confirmed that the destination value perceived by tourists after playing is significantly positively correlated with the possible behavioral intentions of tourists in the future

\subsection{Relationship Between Tourist Destination Image and Tourist Behavior Intention}

For tourists, image is very important. Through in-depth and thorough analysis of tourist destination image, a series of behaviors that tourists may show in the future can be further analyzed. As far as tourists themselves are concerned, destination image not only influences tourists' views on the place, but also influences decision-making process and behavioral intention (Lin et al.2016, Kim et al.2013). Kaesung et al. (2013) investigated tourists participating in Korean sports events and found that destination image has a positive effect on tourists' behavioral intention. Liu et al. (2015) investigated mainland tourists visiting Macau and verified that there was a significant positive relationship between destination image and actual tourists' behavioral intentions. Fu et al. (2016) investigated relevant tourists visiting reality shows and also confirmed that destination image was positively correlated with recommendation intentions. Based on the above, this study proposes the following hypothesis:

H1 Destination image has a significant positive impact on the perceived value.

H2 Destination image has a significant positive impact on the post-visiting behavioral intention.

H3 Perceived value has a significant positive impact on post-visiting behavioral intention.

H4 Perceived value plays a mediating role between destination image and post-visiting behavioral intention.

\section{Research Methodology}

This study is a quantitative research design using survey questionnaire to collect data from Chinese tourists who have finished their tour. Population in this current research are 9.2 million Chinese tourists. Since there is a known population size, the author applied Yamane's Table for the sample size. The result presents 400 samples. The sampling and questionnaire distribution were conducted based on purposive approach. The departure halls of Don Mueang International Airport and Suvarnabhumi International Airport were chosen as the sites for the distribution of questionnaires. After the data collection, the reliability of the data would be tested by Cronbach's Alpha testing. The score was 0.933 . A five-point Likert type scale was used to measure each variable. After the completion of the data process, descriptive, correlation and regression analysis is conducted to test study hypotheses and answer the research questions .

\section{Findings and Discussion}

The results of correlation analysis of the relationship of tourism destination image, perceived value and post-visiting behavioral intention are as follows: 
Table 1. The Relationship of Tourism Destination Image, Perceived Value and post-visiting Behavioral Intention

\begin{tabular}{|c|c|c|c|c|c|c|c|c|c|c|}
\hline & landsc & & & physical & Economic & learning & & revisit & & \\
\hline & image servicee & tertainme & tculture total & value & value & value & total & intention & ommendation & total \\
\hline Landscape image & 1 & & & & & & & & & \\
\hline Service image & $.354 * * \quad 1$ & & & & & & & & & \\
\hline $\begin{array}{l}\text { Entertainment } \\
\text { image }\end{array}$ & $.339 * * .230 * *$ & 1 & & & & & & & & \\
\hline Culture image & $.280 * * .248 * *$ & $.278 * *$ & 1 & & & & & & & \\
\hline total & $.718 * * .648 * *$ & $.701 * *$ & $.661 * * \quad 1$ & & & & & & & \\
\hline Physical value & $.439 * * .228 * *$ & $.398 * *$ & $.218 * * .474 * *$ & 1 & & & & & & \\
\hline Economic value & $.433 * * .315^{* *}$ & $.242 * *$ & $.172 * * .422 * *$ & $.368 * *$ & 1 & & & & & \\
\hline Learning value & $.478 * * .352 * *$ & $.339 * *$ & $.289 * * .713 * *$ & $.442 * *$ & $.436 * *$ & 1 & & & & \\
\hline total & $.816^{* *} .385^{* *}$ & $.417 * *$ & $.294 * * .699 * *$ & $.755^{* *}$ & $.757 * *$ & $.829 * *$ & 1 & & & \\
\hline Revisit intention & $.204 * .125 *$ & $.620 * *$ & $.245 * * .454 * *$ & $.266^{* *}$ & $.154 * *$ & $.195 * *$ & $.260 * *$ & 1 & & \\
\hline Recommendation & n. $307 * * .251 * *$ & $.265^{* *}$ & $.922 * * .638 * *$ & $.224 * *$ & $.192 * *$ & $.313 * *$ & $.316^{* *}$ & $.226 * *$ & 1 & \\
\hline intention & & & & & & & & & & \\
\hline total & $.317 * * .229 * *$ & $.590 * *$ & $.689 * * .680 * *$ & $.315^{* *}$ & $.217 * *$ & $.314 * *$ & $.362 * *$ & $.839 * *$ & $.719 * *$ & 1 \\
\hline
\end{tabular}

The results of Table 1 indicate that There is a significant positive correlation between landscape image, service image, entertainment image, cultural image and physical value, economic value learning value, revisit intention and recommendation intention; physical value, economic value and learning value have significant positive impact on re-visit intention and recommendation intention, which support $\mathrm{H} 1, \mathrm{H} 2, \mathrm{H} 3$.

Table 2. Mediating Effect of Perceived Value Between Destination Image and post-visiting Behavioral Intention

\begin{tabular}{cccc}
\hline & & \multicolumn{2}{c}{ Dependent variables } \\
\cline { 2 - 4 } Independent variables & behavioral intention & Perceived value & $\begin{array}{r}\text { Post-visiting behavioral } \\
\text { intention }\end{array}$ \\
\hline Destination image & $.680^{* * *}$ & $.699^{* * *}$ & $.532^{* * *}$ \\
Perceived value & & & $.221^{* * *}$ \\
$\mathrm{~F}$ & $341.467 * * *$ & $379.750^{* * *}$ & $188.191^{* * *}$ \\
$\mathrm{R}$ & 0.462 & 0.488 & 0.487 \\
\hline
\end{tabular}

Note: $* \mathrm{P}<0.05, \quad * * \mathrm{P}<0.01, * * * \mathrm{P}<0.001$

Table 2 shows that the destination image is an independent variable and the post-visiting behavioral intention is a dependent variable. The destination image has a significant positive effect on the post-visiting behavioral intention $(\beta=0.680, \mathrm{P}<0.001)$; and regression 2 destination image is an independent variable and the perceived value is a dependent variable. The destination image has a significant positive effect on the perceived value $(\beta=0.699, \mathrm{P}<0.001)$; Regression 3, with destination image and perceived value as independent variables, post-visiting behavioral intention as dependent variable, destination image has significant positive effect on behavioral intention $(\beta=0.532, \mathrm{P}<0.01)$, which is less than the coefficient in regression 1 . It shows that the perceived value plays a partial mediating effect in the influence of the destination image on the post-visiting behavioral intention, which supports $\mathrm{H} 4$.

The close relationship between tourism destination image and perceived value has always been the focus of scholars. Lban et al .(2015) take the festival tour as an example, the results show that the image of the tourist destination affects the perceived value and further affects the tourist's intention to visit again; there is a significant impact of destination image on behavioral intention. As far as tourists themselves are concerned, the 
image of destination not only affects the tourists' views on the place, but also affects the decision-making process and behavior intention; perceived value of tourists not only plays an important role in the pre-visit decision, It will also play a role in their related behavior after sightseeing. Petrick (2004) noted that, Perceived value can have an effect on the intention of tourists to recommend destinations and their intention to revisit in the future, In other words, Higher perceived value will lead to greater recommendation and revisiting intention, perceived value plays a partial mediating effect in the influence of the destination image on the behavioral intention.

\section{Conclusion and Recommendations}

\subsection{Conclusion}

For the destination, the tourist's revisiting behavior can not only help to reduce the marketing cost of the enterprise, but also make the destination maintain a high number of tourists, realize stable economic benefits, and even play the role of information dissemination channel. Spread word of mouth to potential tourists. This paper reviews and summarizes the relevant literature of previous scholars, and discusses the role of destination image on behavior intention. The selected sample is Chinese tourists in Thailand. Tourism destination image is the starting point of the theoretical research framework. Taking perceived value as the research path, this paper constructs the model of tourism destination image, perceived value and tourist behavior intention, and makes an empirical study on it through correlation analysis and regression analysis. Moreover, the mediating effect of perceived value is analyzed, and the following research conclusions are drawn in this study.

(1) tourism destination image positively affects the perceived value of tourists. This paper uses empirical test to find that perceived value will increase with the improvement of destination image. That is to say, tourists will feel a better tourist image after the destination tour, and tourists will feel that the value of this trip is higher. This is consistent with the previous research conclusions, indicating that the perceived value of tourists after travel and play has a great relationship with the image of tourist destination.

(2) Perceived value positively influences the behavior intention of tourists. The empirical results show that the higher the perceived value, the stronger the future behavior intention. Therefore, the perceived value of passengers can not only directly affect the behavior intention of tourists, but also play an intermediary effect between destination impression and behavior intention.

(3) The image of tourist destination has a positive influence on the behavior intention of tourists. Through the data analysis, the results show that the perceived value will increase with the improvement of the image of the tourist destination, and the behavior intention of the tourists in the future will increase with the enhancement of the perceived value. Therefore, destination image can not only directly affect behavioral intention, but also indirectly affect it through perceived value.

(4) Perceived value plays a partial mediating effect between destination image and post-visiting behavioral intention of Chinese tourists to Thailand. Through the test of mediating role, the destination image has a significant positive effect on the post-visiting behavioral intention $(\beta=0.680, \mathrm{P}<0.001)$; The destination image has a significant positive effect on the perceived value $(\beta=0.699, \mathrm{P}<0.001)$; destination image has significant positive effect on post-visiting behavioral intention $(\beta=0.532, \mathrm{P}<0.01)$, which is less than the coefficient 0.680 . It shows that the perceived value plays a partial mediating effect in the influence of the destination image on the post-visiting behavioral intention.

\subsection{Recommendation}

Based on the findings, some recommendations for the organizations are suggested as follows:

(1) Enhance the image of tourist destination. The good image of tourist destination can improve the perceived value of tourists, and then improve their recommendation intention and re-visit intention. Therefore, it is of positive significance to optimize the image of tourist destination.

(2) Improve the perceived value of tourists. If a tourist destination wants to enjoy a high reputation, so that tourists have the idea of repeated play, it should first ensure that tourists are provided with a high value tourism experience, so that tourists can really realize that the tour is worth the money when weighing the benefits received and the time, money and energy paid. In order to enhance the perceived value of tourists, tourism destination enterprises should strive to improve the quality of tourism products and services, provide authentic products and services; on the other hand, tourist destinations should provide reasonable prices for food, accommodation, transportation, tourism, shopping, entertainment and other industries, so that tourists feel that consumption is worth it in the course of tourism. The quality and price of services received are commensurate with the time and money spent. In order to establish a close relationship between passengers and destinations, and finally achieve the purpose of return visit and recommendation. 


\section{3 limitations and Future Research}

(1) this study selected Thailand as a tourist destination, the conclusion of the study may with similar tourist destinations in Thailand, which is not enough to reflect the general situation of different countries in the world. The future research can select other types of tourist destinations which are different from Thailand as the research object, and test the validity and universality of the research conclusions.

(2) the research time of this study is concentrated in September-December, because the time limit does not carry on the long-term and repeated investigation, the research result may have the deviation. Therefore, in future studies, we can try to collect samples at different times or expand the recovery time of samples, so as to reduce the possible sample deviation. Thus, the results of the same tourist destination at different seasons are tested.

(3) this study, we explore the influence mechanism of the independent variable of tourist destination image on the dependent variable of tourists' possible behavior intention in the future, and select the perceived value as the intermediary variable. Other variables that may have a related impact on tourist behavior intention are ignored. Therefore, in the future, we can try to add variables such as psychological distance to improve the study of this paper.

\section{References}

Aliman, N. K., Hashim, S. M., \& Wahid, S. D. M. (2014). Tourist expectation, perceived quality and destination image: Effects on perceived value and satisfaction of tourists visiting langkawi Island, Malaysia. Asian Journal of Business and Management, 2(3), 212-222.

Bai, L. M. (2007). Study on the Theory and Method of Image Measurement of Tourism Destination - Taking Yangshuo Guilin as an example. Nanning: Guangxi University.

Bai, Z. P. (2015). A Study on the Influence of Perceived Image on Tourist Loyalty in Cultural Famous Buildings Changsha: Hunan Normal University.

Cai, W. M. (2015). Study on perceived value and intention of revisiting in rural tourist destinations - Taking Sansheng Township of Chengdu as an example. Journal of Southwest University for Nationalities, 5, 134-138.

Castro, C. B., Armario, E. M., \& Ruiz, D. M. (2007). The influence of market heterogeneity on the relationship between a destination's image and tourists' future behavior. Tourism Management, 28(1), 175-187. https://doi.org/10.1016/j.tourman.2005.11.013

Chen, C. C., Lai, Y. H., \& Petrick, J. F. et al. (2016). Tourism between divided nations: an examination of stereotyping on destination image. Tourism Management, 55, 25-36. https://doi.org/10.1016/j.tourman.2016.01.012

Chen, C. F., \& Chen, F. S. (2010). Experience quality, perceived value, satisfaction and behavioral intentions for heritage tourists. Tourism Management, 31(1), 29-35. https://doi.org/10.1016/j.tourman.2009.02.008

Chen, C. F., \& Tsai, D. C. (2007). How destination image and evaluative factors affect behavioral intentions? Tourism Management, 28(4), 1115-1122. https://doi.org/10.1016/j.tourman.2006.07.007

Chi, G. Q., \& Qu, H. (2008). Examining the structural relationships of destination image, tourist satisfaction and destination loyalty: An integrated approach. Tourism Management, 29(4), 624-636. https://doi.org/10.1016/j.tourman.2007.06.007

Cheng, T. M., \& Lu, C. C. (2013). Destination image, novelty, hedonics, perceived value, and revisiting behavioral intention for island tourism. Asia Pacific Journal of Tourism Research, 18(7), 766-783. https://doi.org/10.1080/10941665.2012.697906

Duman, T., \& Mattila, A. S. (2005). The role of affective factors on perceived cruise vacation value. Tourism Management, 26(3), 311-323. https://doi.org/10.1016/j.tourman.2003.11.014

Endah, P. E., Umar, N., \& Suharyono, S. et al. (2017). Study on destination image, satisfaction, trust and behavioral intention. Russian Journal of Agricultural and Socio-Economic Sciences, 61(1), 148-159. https://doi.org/10.18551/rjoas.2017-01.15

Fakeye, P. C., \& Crompton, J. L. (1991). Image Differences between prospective, First-Time, and Repeat Visitors to the Lower Rio Grande Valley. Journal of Travel Research, 30(2), 10-16. https://doi.org/10.1177/004728759103000202

Fishbein, M., \& Ajzen, I. (1975). Belief, attitude, intention and behavior: an introduction to theory and research. Philosophy \& Rhetoric, 41(4), 842-844.

Fu, H., Ye, B. H., \& Xiang, J. (2016). Reality TV, audience travel intentions, and destination image. Tourism 
Management, 55, 37-48. https://doi.org/10.1016/j.tourman.2016.01.009

Gartner, W. C. (1993). Communication and channel systems in tourism marketing. Journal of Travel \&Tourism Marketing, 26(1), 31-38.

Guan, X. H., Li, J. Y., \& Xie, L. S. (2015). The influence of tourism public service quality on tourism destination image. Tourism science, 29(5), 27-38.

Gunn, C. A. (1972). Vacationscape: Designing tourist regions. Austin: Bureau of Business Research, University of Texas, 114 .

Guo, A. X., Huang, F. C., \& Li, W. (2013). The Empirical Study on the Key Drivers of Revisiting Intention Comparison of Perceived Value, Perceived Attraction, Tourist Satisfaction and Tourist Trust. Journal of Jiangxi University of Finance and Economics, 1, 38-46.

Guo, A. X., Zhang, Y. F., \& Guo, Y. Z. et al. (2019). Influence Mechanism of Tourist Perceived Value Dimension on Revisiting Intention - Based on the Perspective of Team Tourists. World Geographic Studies, 28(1), 197-207.

Han, C. X. (2015). The Relationship between Tourism Perceived Value and Satisfaction and Behavioral Intention. Human Geography, 3, 137-144.

$\mathrm{Hu}, \mathrm{X}$. Y., Bai, K., \& Wang, L. (2013). Image restoration strategy of tourist destination: scale development and test of association behavior intention. Human Geography, 5, 139-146.

Huang, Y. H., \& Huang, F. C. (2007). Study on the Value Model, Measurement and Empirical Study of Tourist Perception. Journal of Tourism, 22(8), 42-47.

Hutchinson, J., Lai, F., \& Wang, Y. (2009). Understanding the relationships of quality, value, equity, satisfaction, and behavioral intentions among golf travelers. Tourism Management, 30(2), 298-308. https://doi.org/10.1016/j.tourman.2008.07.010

Hyun, S. S., Wansoo, K., \& Lee, M. J. (2011). The impact of advertising on patrons' emotional responses, perceived value, and behavioral intentions in the chain restaurant industry: the moderating role of advertising-induced arousal. International Journal of Hospitality Management, 30(3), 689-700. https://doi.org/10.1016/j.ijhm.2010.10.008

Jin, N., Lee, H., \& Lee, S. (2013). Event quality, perceived value, destination image, and behavioral intention of sports events: The case of the IAAF World Championship, Daegu, 2011. Asia Pacific Journal of Tourism Research, 18(8), 849-864. https://doi.org/10.1080/10941665.2012.711336

Kaesung, M., Ko, Y. J., \& Connaughton, D. P. et al. (2013). A mediating role of destination image in the relationship between event quality, perceived value, and behavioral intention. Journal of Sport Tourism, 18(1), 49-66. https://doi.org/10.1080/14775085.2013.799960

Kim, S. H., Holland, S., \& Han, H. S. (2013). A structural model for examining how destination image, perceived value, and service quality affect destination loyalty: A case study of Orlando. International Journal of Tourism Research, 15(4), 313-328. https://doi.org/10.1002/jtr.1877

Lban, M. O., Kaşli, M., \& Bezirgan, M. (2015). Effects of destination image and total perceived value on tourists' behavioral intentions: an investigation of domestic festival tourists. Tourism Analysis, 20(5), 499-510. https://doi.org/10.3727/108354215X14411980111370

Lee, C. K., Yoon, Y. S., \& Lee, S. K. (2007). Investigating the relationships among perceived value, satisfaction, and recommendations: The case of the Korean DMZ. Tourism Management, 28(1), 204-214. https://doi.org/10.1016/j.tourman.2005.12.017

Li, W. (2015). Study on the influence of service scenario on store attachment and customer behavioral intention. Dalian: Dongbei University of Finance and Economics.

Li, W. B., \& Zhang, H. M. (2010) Conceptual Model of tourist Perceived Value in Ancient Villages and Empirical Research - A Case study of Zhang Guying Village. Tourism Science, 24(2), 55-63.

Lin, C. H., \& Chin, C. T. (2016). A study of the travel information resources, destination image, and behavioral intention of college students on Kenting. Asian Journal of Business and Management, 4(6), 239-247.

Liu, J. Y., \& Jing, J. J. (2015). Study on the Influence of Religious Tourism Experience on Tourist's Behavioral Intention - Intermediation of Tourist's Mood. Tourism Science, 29(3), 36-48.

Liu, X., Li, J., \& Kim, W. G. (2015). The role of travel experience in the structural relationships among tourists' perceived image, satisfaction, and behavioral intentions. Tourism \& Hospitality Research, 11(8), $225-232$. 
Ma, L., \& Bao, J. G. (2012). The traditional festival tourism experience from the perspective of perceived value - Taking Xishuangbanna Dai Water splashing Festival as an example. Geography Studies, 31(2), 269-278.

Mc, C. (1999). Understanding the relationships between tourist's emotional experiences, perceived overall image, satisfaction, and intention to recommend. Journal of Travel Research, 12, 1-14.

Morrison, A. P. (1998). A cognitive analysis of the maintenance of auditory hallucinations:Are voices to schizophrenia what bodily sensations are to panic. Behavioral and Cognitive Psychotherapy, 26(4), 289-302. https://doi.org/10.1017/S1352465898264010

Papadimitriou, D., Apostolopoulou, A., \& Kaplanidou, K. (2015). Destination personality, affective image, and behavioral intentions in domestic urban tourism. Journal of Travel Research, 54(3), 223-229. https://doi.org/10.1177/0047287513516389

Petrick, J. F. (2004). The roles of quality, value, and satisfaction in predicting cruise passengers' behavioral intentions. Journal of Travel Research, 42(4), 397-407. https://doi.org/10.1177/0047287504263037

Prayag, G., \& Ryan, C. (2012). Antecedents of tourists' loyalty to mauritius the role and influence of destination image, place attachment, personal involvement, and satisfaction. Journal of Travel Research, 51(3), 342-356. https://doi.org/10.1177/0047287511410321

Prayag, G., Hosany, S., \& Muskat, B. et al. (2015). Understanding the relationships between tourists' emotional experiences, perceived overall image, satisfaction, and intention to recommend. Journal of Travel Research, 56(1), 41-54. https://doi.org/10.1177/0047287515620567

Sanchez, J., Callarisa, L., \& Rodriguez, R. M. et al. (2006). Perceived value of the purchase of a tourism product. Tourism Management, 27(3), 394-409. https://doi.org/10.1016/j.tourman.2004.11.007

Shican. (2017). Study on the relationship between tourist destination image and tourist satisfaction and loyalty - take the special town around Xiong'an New District as an example. Hebei Enterprise, 5, 92-93.

Son, A. (2005). The measurement of tourist destination image: Applying a sketch map technique. International Journal of Tourism Research, 7, 279-284. https://doi.org/10.1002/jtr.532

Su, L. J., \& Huang, F. C. (2010). Influencing Factors on Tourist Image Perception and Its Influence on Loyalty. Business Economics and Management, 1(6), 80-88.

Tu, H. W., Xiong, L. Y., \& Huang, Y. M. et al. (2017). Effect of Destination Image on Tourist's Behavioral Intention - Based on Theory of Emotional Evaluation. Journal of Tourism, 32(2), 32-41.

Woodruff, R. B. (1997). Customer value: the next source for competitive advantage. Journal of the Academy of Marketing Science, 25(2), 139-153. https://doi.org/10.1007/BF02894350

Wu, H. C., Tao, L., \& Li, M. Y. (2016). A study of behavioral intentions, patient satisfaction, perceived value, patient trust and experiential quality for medical tourists. Journal of Quality Assurance in Hospitality \& Tourism, 17(2), 114-150. https://doi.org/10.1080/1528008X.2015.1042621

Yang, N., Gao, J., \& Lu, C. Y. et al. (2015). Study on the Relationship between Urban Tourism Image and Tourist Behavior Intention Based on SEM - Taking Xi'an as an Example. Resources and Environment in Arid Zones, 29(2), 190-195.

Žabkar, V., Brenčič, M. M., \& Dmitrović, T. (2010). Modelling perceived quality, visitor satisfaction and behavioral intentions at the destination level. Tourism Management, 31(4), 537-546. https://doi.org/10.1016/j.tourman.2009.06.005

Zeithaml, V. A. (1988).Consumer perceptions of price, quality, and value: A Means-End model and synthesis of evidence. Journal of Marketing, 529, 2-22. https://doi.org/10.1177/002224298805200302

Zeithaml, V. A., Berry, L. L., \& Parasuraman, A. (1996). The behavioral consequences of service quality. The Journal of Marketing, 60(2), 31-46. https://doi.org/10.2307/1251929

Zhao, J. Y., Ma, P., \& Lu, Z. Y. (2013). Relationship between image, perceived value and tourist loyalty of hot spring tourist destination - taking Tang Gangzi in Liaoning Province as an example. Enterprise economy, 3, 129-132.

\section{Copyrights}

Copyright for this article is retained by the author(s), with first publication rights granted to the journal.

This is an open-access article distributed under the terms and conditions of the Creative Commons Attribution license (http://creativecommons.org/licenses/by/4.0/). 